\title{
公表資料による住宅ストックの時期別戸数の推定 ESTIMATION ON A NUMBER OF HOUSING STOCKS BY CONSTRUCTION ÝEAR
}

\author{
大野隆司* \\ Takashi OHNO
}

This study is mainly considered in the points that follow, through the comparison of the Housing Survey, conducted every 5 years, about housing stocks and the statistics of building starts and losses.

1. There is a material about a number of housing stocks by construction year in the last 5 years every report of the Housing Survey.

2. In many cases, a number of housing stocks in a survey conducted-year is too large comparing the actual condition. But it in one term including the year is natural.

3. A remaining ratio of housing stocks is proportional to years passed since construction year for several decades.

4. A number of destructed-houses in the statistics of building starts and losses is too few.

5. A number of housing stocks estimated by the statistics of building starts and losses is very similar to it by the Housing Survey.

Keywords: Housing Survey, Occupied dwelling, Construction year, Statistics of building starts and losses,

Housing stock, Remaining ratio

住宅統計調査、居住世帯のある住宅、建築時期、建築動態統計、住宅ストック、残存率

\section{1. はじめに}

省資源、廃棄物削減など様々な理由もあって、いわゆるスクラッ プアンドビルドでなく改修や増・改筑によって、住宅改善を進める 傾向が顕著になりつつある。既存の住宅の規模を算定するに際して どの程度のレベルのものが、どの位あるかを定量的に推定するため には、構造や防火規定にかかわる建築基準法など関連法規や、省工 ネルギー基準など各種基準類、さらには各種の仕様書類などの改訂 年と関連づける意味で、住宅ストックについて建築の時期別、ある いは年別（1年単位の意、以下同じ）のデータが必要となる。

住宅ストックについては 5 年每に総務庁統計局による住宅統計 調査がなされ、公表される。しかしながらこのデータのうち総住宅 数については、各調査時点において存在する戸数が示されているだ けで（都道府県別デ一夕はある）、建築の時期（完成の時期）別の 戸数がわかるのは居住世帯のある住宅だけである(居住世帯のある 住宅数を総住宅数と区別する急味で以下、居住宅数という）。ただ しこの場合も、調查方法 (具体的にはアンケート用紙にある選択肢) との関係から調查年直近の過去約 5 年間を除いては、 5 年か 10 年、
あるいはそれ以上の期間に対して戸数が調査・集計されるだけで (この記入・集計区分である建築時期の区切りを以下、期区という)、 年別には対応していない。

時期別のデータとしては、建設省建設経済局による建築動態統 計調査の建築着工統計や建築物㓕失統計があり、住宅については 前者の住宅着工統計と後者の居住用建築物のデータが対応してい るが、これはあくまでも住宅のフロー・データであり、ストックの 内容を示すものではない。

本論文は住宅統計調查の結果を使って建築動態統計調查のデ 一夕を加工し、住宅ストックの時期別データ（法規・基準などの 改訂と関連づけるためには着工時期別のストック・データが望ま しい）を概算する方法とその結果について検討するものである。

\section{2. 年別の居住宅数データの抽出}

住宅統計調査は昭和 23 年の第 1 回調査を除いてストック全体 に対する悉皆調査ではなく、全国平均約 5.5 分の 1 の調査区につ いて、その概ね半分の地域に対するサンプリング調查によること

\footnotetext{
$*$ 東京工芸大学工学部建築学科 教授・而博 Prof., Dept. of Architecture, Faculty of Engineering, Tokyo Institute of
} Polytechnics, Dr. Eng. 
から、統計上ある程度の誤差は避けられないもの であること、また、調查の多くは住まい手に対す るアンケートの回答結果であり、判断・記憶違い などを免れないものであることなど、結果が害態 と異なる可能性を有している。

この他に建築時期のデータが実態と異なる可能 性としては、居住者不在で居住宅数の対象でなくな る場合、建築時期不詳と回答される場合などがある。 前者の場合はその調査時点では実質的には堿失し

たものと同様の扱いになり、後者の場合もやはり該当する建築時期 について减失したものと同様の扱いになる。以下の検討においても この種の調査・集計上の限界に留意する必要があり、居住宅数と住 宅総数、居住宅数と建築時期不詳戸数、の関係を調查年毎に表 1 に 示す。いずれの調查においても居住宅数は総住宅数に比べて数\%〜 十数\%少なく、そのうちの $0 \%$ ～$\%$ が建築時期不詳である。

表 2 はこれまでの住宅統計調査に関する公表資料から年別の居 住宅数（全国、全住宅）のデータを抜粋した結果である（1955年 以前汭な、また後述する計算に利用する $2 、 3$ 年単位のデー夕も あわせて示す)。このうち各調查年における居住宅数のデー夕は、 調査が10月前後と年の途中であることから、1958、1963、1968、 1973年についてはそれぞれ次回の調査結果によるものとすれば、 1978、1983、1988、1993年を除いて各調查時点の前年まで 5 年間 については住宅ストックの年別データがあることになる。なお、住 宅統計調査、動態統計調查とも1973年調查より冲縄県が含まれる が、その影響は極めて僅かである（表 4 参照）。

\section{3. 年别の住宅ストックの集定}

住宅統計調查において建築時期をとらえる大枠はおおよそ決ま っているが、その区切り（本論でいう期区）は調査年によって微 妙に異なっている。戸数の経年変化をとらえるためには共通の期 区を設定する必要があり、ここでは最も頻出度合いの高い、
表2. 住宅統計調查の年別居住宅数 (着エ戸数)

\begin{tabular}{|c|c|c|c|c|}
\hline 調查年 & 建築年 & 居住宅数 & $\begin{array}{l}\text { 次回調查: } \\
\text { 居住宅数 }\end{array}$ & $\begin{array}{l}\text { 謩考: } \\
\text { 着工戸数 }\end{array}$ \\
\hline \multirow{3}{*}{1958} & 1956 & 518,000 & 438,000 & \begin{tabular}{|l|}
308,686 \\
\end{tabular} \\
\hline & 1957 & 615,000 & 577,000 & 321,095 \\
\hline & 1958 & 422,000 & 608,000 & 337,989 \\
\hline \multirow{5}{*}{1963} & 1959 & 666,000 & & 380,575 \\
\hline & 1960 & 745,000 & & 424,170 \\
\hline & 1961 & 865,000 & 967,800 & 535,963 \\
\hline & 1962 & 913,000 & 898,300 & 586,122 \\
\hline & 1963 & 621,000 & $1,240,000$ & 688,743 \\
\hline \multirow{5}{*}{1968} & 1964 & $1,161,100$ & & 751,429 \\
\hline & 1965 & $1,149,900$ & & 842,596 \\
\hline & 1966 & $1,139,600$ & \multirow{2}{*}{$2,642,200$} & 856,579 \\
\hline & 1967 & $1,172,100$ & & 991,158 \\
\hline & 1968 & \begin{tabular}{|l|}
776,100 \\
\end{tabular} & $1,547,900$ & $1,201,675$ \\
\hline \multirow{5}{*}{1973 * } & 1969 & $1,432,200$ & & $1,346,612$ \\
\hline & 1970 & $1,592,500$ & & $1,484,556$ \\
\hline & 1971 & $1,584,900$ & \multirow{2}{*}{$3,612,800$} & $1,463,760$ \\
\hline & 1972 & $1,562,200$ & & $1,807,581$ \\
\hline & 1973 & 929,200 & $1,798,200$ & $1,905,112 *$ \\
\hline \multirow{5}{*}{1978} & 1974 & $1,458,400$ & & $1,316,100$ \\
\hline & 1975 & $1,298,700$ & & $1,356,286$ \\
\hline & 1976 & $1,301,300$ & \multirow{3}{*}{$\begin{array}{r}4,405,100 \\
(2081063) \\
\end{array}$} & $1,523,844$ \\
\hline & 1977 & $1,165,500$ & & $1,508,260$ \\
\hline & 1978 & 706,600 & & $1,549,362$ \\
\hline \multirow{5}{*}{1983} & 1979 & $1,380,200$ & & $1,493,023$ \\
\hline & 1980 & $1,178,100$ & & $1,268,626$ \\
\hline & 1981 & $1,099,700$ & \multirow{3}{*}{$\begin{array}{l}3,563,700 \\
(1547423)\end{array}$} & $1,151,699$ \\
\hline & 1982 & $1,011,000$ & & \begin{tabular}{|l|}
$1,146,149$ \\
\end{tabular} \\
\hline & 1983 & 594,700 & & $1,136,797$ \\
\hline \multirow{5}{*}{1988} & 1984 & $1,098,100$ & & $1,187,282$ \\
\hline & 1985 & $1,161,400$ & & $1.236,072$ \\
\hline & 1986 & $1,157.100$ & \multirow{3}{*}{$\begin{array}{l}3,853,900 \\
(1559832)\end{array}$} & $1,364,609$ \\
\hline & 1987 & $1,244,400$ & & $1,674,300$ \\
\hline & 1988 & 894,500 & & $1,684,644$ \\
\hline \multirow{5}{*}{1993} & 1989 & $1,734,000$ & & $1,662,612$ \\
\hline & 1990 & $1,395,300$ & & $1,707,109$ \\
\hline & 1991 & $1,217,100$ & \multirow{3}{*}{$\begin{array}{l}3,694,400 \\
(1501590) \\
\end{array}$} & $1,370,126$ \\
\hline & 1992 & $1,078,400$ & & \begin{tabular}{|l|}
$1,402,590$ \\
\end{tabular} \\
\hline & 1993 & 785,000 & & $1,485,684$ \\
\hline \multirow{5}{*}{1998} & 1994 & $1,225,900$ & & $1,570,252$ \\
\hline & 1995 & $1,382,800$ & & $1,470,330$ \\
\hline & 1996 & $1,356,100$ & & $1,643,266$ \\
\hline & 1997 & $1,235,800$ & & $1,387,014$ \\
\hline & 1998 & 752,900 & & $1,198,295$ \\
\hline
\end{tabular}

().1973年より両統計とも沖縄県含む 終戦前、終戦～1950年、1951 1960年、1961 $\sim 1970$ 年、1971〜1980年、1981〜1990年、 1991年〜の 7 期区とした。表 3 は調査年別・ 期区別の居住宅数である。住宅統計調查のうち 現状では最も新しい結果である1998年のデー夕 を使って以下のように、1998年調査時点での年 別の住宅ストックの算定を試みる。

1998年調査の記入・集計単位の期区内にある 住宅ストックについては年あたりの减失率が等 しいとすれば、1998年の結果は経過年数を考慮 した調査年の結果に比例するから、A 年調査に 表3. 建築の時期別住宅ストック(戸数)の変遷

\begin{tabular}{|c|c|c|c|c|c|c|c|}
\hline 調查年 & 終戦前 & $\begin{array}{l}\text { 終戦〜1950 } \\
\text { 年 } \\
\end{array}$ & $1951 \sim 60$ 年 & 1961～70年 & 1971 80年 & 1981～90年 & 1991年〜 \\
\hline 1948 & $12,207,704$ & $1,640,065$ & & & & & \\
\hline 1953 & (集計方法t & 今ど他と異なる & 点多いため & 除外) & & & \\
\hline 1958 & $10,739,000$ & $2,581,000$ & \begin{tabular}{|l|}
$3,907,000$ \\
\end{tabular} & & & & \\
\hline 1963 & $9,943,000$ & $2,370,000$ & $5,647,000$ & $2,399,000$ & & & \\
\hline 1968 & $8,496,600$ & 7.185 & 5.800 & $8,504,900$ & & & \\
\hline 1973 & $6,227,700$ & $1,805,800$ & $4,425,800$ & $12,178,900$ & $4,076,300$ & & \\
\hline 1978 & $4,902,300$ & $1,498,200$ & $4,123,100$ & $10,232,100$ & $11,341,500$ & & \\
\hline 1983 & $3,670,000$ & $1,266,100$ & $3,471,500$ & $8,870,100$ & $14,473,200$ & $2,705,400$ & \\
\hline 1988 & $2,701,400$ & 993,300 & $2,821,300$ & $7,671,900$ & $13,542,500$ & $9,119,200$ & \\
\hline 1993 & $2,144,300$ & 824,500 & $2,373,100$ & $6,489,000$ & $12,530,500$ & $12,375,300$ & $3,080,500$ \\
\hline 1998 & $1,647,100$ & 668,400 & $1,932,700$ & $5,476,300$ & $11,491,600$ & $11,973,000$ & $9,650,100$ \\
\hline (参考) & $1,645,300$ & 661,500 & $1,909,700$ & $5,426,600$ & $11,369,900$ & $11,850,700$ & $9,569,200$ \\
\hline
\end{tabular}
よる $\mathrm{B}$ 年の1998年調査時点での住宅ストック戸 数 $\mathrm{S}_{\mathrm{B} 98}$ は次式で計算できる。

$\mathrm{S}_{\mathrm{B} 98}=\mathrm{S}_{\mathrm{B} \mathrm{A}}[1-\alpha \times(1998-\mathrm{A})]$

ここで $\mathrm{S}_{\mathrm{BA}}: \mathrm{B}$ 年の $\mathrm{A}$ 年調查時点での住宅ストック戸数 $\alpha: 1998$ 年調査の $\mathrm{B}$ 年を含む期区の住宅ストックの年あ たり减失率（最新調查年データとの比例、という意味 から以下、比例减失率という)

この結果を1998年調査の期区にわたって合計した $\Sigma \mathrm{S}$ は、1998

表 4. 隇失率と(経過年数と残存率との)相関係数

\begin{tabular}{|c|c|c|c|c|c|c|}
\hline & 終戦前 & $\begin{array}{l}\text { 終戦 } \\
\text { 1950年 }\end{array}$ & $\begin{array}{l}1951 \sim \\
60 \text { 年 }\end{array}$ & $\begin{array}{l}1961 \sim \\
70 \text { 年 }\end{array}$ & \begin{tabular}{|l|}
$1971 \sim 2$ \\
80 年
\end{tabular} & $\begin{array}{l}1981 \sim \\
90 \text { 年 }\end{array}$ \\
\hline 比例滅失率\% & 2.117 & 1.853 & 1.700 & 1.912 & 1.157 & 0.895 \\
\hline 回帰滅失率\% & 1.942 & 1.933 & $\begin{array}{l}1.895 \\
\end{array}$ & 2.156 & 1.376 & 0.650 \\
\hline 勾配b & (1.943) & $(1.948)$ & $(1.920)$ & $(2.155$ & & \\
\hline 相関係数 & 0.9866 & 0.9963 & 0.9977 & 0.9936 & 0.9997 & - \\
\hline サンプル数 & 10 & 8 & & & 4 & \\
\hline 有意水準: $1 \%$ & 0.765 & 0.834 & 0.874 & 0.917 & 0.990 & - \\
\hline
\end{tabular}


年調査の当該期区の住宅ストック戸数（表 3 参照）と一致する筈で あることから滅失率 $\alpha$ を逆算し、その結果を使って1998年時点で の年別の住宅ストック $\mathrm{S}_{\mathrm{B} 98}$ を算出し、図 9 に（後述の着工戸数か ら算定した結果などとあわせて）示す。1978、1983、1988、199 3年は年別データがないことから、それぞれ次回調査における前年、 前々年を含むデー夕を使って比例减失率を算出し、その結果を利用 する。例えば1978年の場合、次回調査にある1976 1978年の合計 值を使って得られた比例减失率により、次回調査時点での1976、1 977年の推定値を算出し、それらを1976 1978年の合計值から差 し引いた値とした。なお、1991、1992年については减失率の定め ようがないため、ここでは便宜的に1981〜1990年の减失率を援用 して算出した。逆算によって求められ、ストック算定に使用された 期区別の比例减失率を表 4 に示す。

表 2 に示すように、算出した1978、1983、1988、1993年のデー 夕を含め調査年における居住宅数の多くは前後の年に比べ異常に 大きい。（調査時点から最も遠い年のデータであり）この種のアン ケート調査では建築時期について錯誤の入る可能性を考慮する必 要がある。ここでは一般的な統計手法である移動平均によるものは 居住宅数の期区合計に影響することから、以下のように調査年を含 む前後 3 年間だけで調查年データを均すこと（以下、平準化という） を考えた。

$$
\begin{aligned}
& \mathrm{a}_{\mathrm{H}}=(7 \times \mathrm{a}+4 \times \mathrm{b}+\mathrm{c}) / 12 \\
& \mathrm{~b}_{\mathrm{H}}=(\mathrm{a}+\mathrm{b}+\mathrm{c}) / 3 \\
& \mathrm{c}_{\mathrm{H}}=(\mathrm{a}+4 \times \mathrm{b}+7 \times \mathrm{c}) / 12
\end{aligned}
$$

ここで、調査前年居住宅数を $a$ 、調査年居住宅数を $b$ 、調査翌年 居住宅数を $\mathrm{c}$ とし、平準化後のそれらを $\mathrm{a}_{\mathrm{H}} 、 \mathrm{~b}_{\mathrm{H}} 、 \mathrm{c}_{\mathrm{H}}$ とする。

\section{4. 期区成失本の算定}

表 3 をもとにそれぞれの期区の中間年から各調査年までの年 数（以下、平均経過年数という）を横軸に、各期区について最も 古い調査時点における居住宅数に対するその後の各調査時点で の（残存する）居住宅数の割合（以下、残存率という）を縦軸に とってプロットしたものが図 1 〜図 5 である（1981〜1990年に ついては 2 点であり図は省略した）。期区のうち終戦前について は中間年が不明であるが、ここでは便宜的に1928年（1998年調 査時点で平均70年経過したもの）として示している。いずれの期 区においてもサンプル数は少ないものの表 5 に示すように平均 経過年数と残存率との相関係数は極めて高く、回㷌直線（残存率 $=\mathrm{a} \times$ 経過年数 $+\mathrm{b})$ を求め図示した。また、この種の残存率の 回帰でよく利用されるロジスティック曲線注 1)についても以下に よるものとし、あわせて図 1 〜図 5 に示した（いずれも水準 $1 \%$ で有意である）。

残存率 $=120 /\left(1+\mathrm{C} \times \mathrm{e}^{-\mathrm{t} \times \text { 経週年数 }}\right)$

ここで 120 : 直線回帰での y 切片 bを参考に、デー夕と曲線と ができるだけ近似するよう設定した共通の上限值

$\mathrm{C} 、 \mathrm{t}$ : 回帰により算出される定数

このプロット結果と回帰直線・曲線とを比べてみると、平均経 過年数が数年〜数十年（具体的には終戦前や終戦後〜1950年を除 き）では直線による回帰の近似度は高く、線形と考えることがで きる。直線回帰で算出される勾配 $\mathrm{a}$ は残存率の年あたりの減少を
示し、それぞれの期区につ いて居住世帯のある住宅の 平均的な年あたり减失率 (以下、回帰減失率という) を表示している。線形であ る期区毎の傾向は比例减失 率とよく似ている。

また、y 切片 $\mathrm{b}$ は建築当 初の戸数、 $\mathrm{x}$ 切片 $-\mathrm{b} / \mathrm{a}$ は住宅の寿命に相当する。 しかしながら、図 1 や図 2 に示す比較的長期間にわた るプロット結果や、この種 の残存率の一般的な傾向を 考慮すれば、直線回帰は数 年〜数十年の範囲に限って 適用すべきであり（〜数年 や数十年〜は勾配が緩い可 能性がある）、その意味か らは上述の $\mathrm{y}$ 切片や $\mathrm{x}$ 切片 ・の解釈はあくまで相対的な 目安を示すものととらえる ベきであろう。

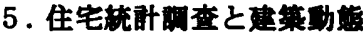

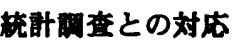

建築動態統計調查は届け を要する全てが対象である が、その根拠である「建築 工事届」や「建築除却届」 があくまで予定（「建築物 災害報告書」は結果) であ り工事中止・変更がありう ることや、「建築工事届」 には増策・改筑を含むこと など寒態より大きい危険性 が、逆に $10 \mathrm{~m}^{2}$ 以下の場合は 「建築工事届」を要しない ことなど実態より小さい危 険性が、それぞれ考えられ、 住宅統計調查とは異なる誤 差の可能性が指摘できる。

動態統計調査のデー夕に これまで検討した住宅統計 調查の結果を適用するには 前者の着工時期と後者の建 筑時期との対応を調べる必 要がある。住宅統計において 最も動態統計に近い結果を 示すと思われる調査前年の

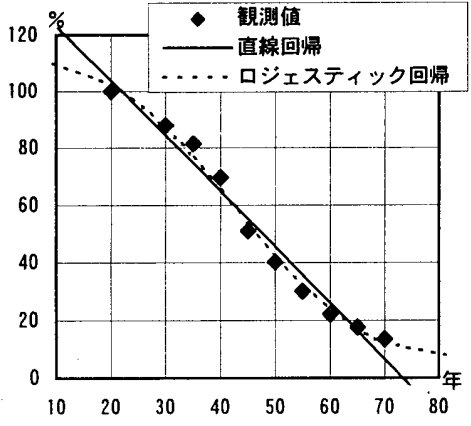

図 1，居住宅数残存率の変遷（終戦前）

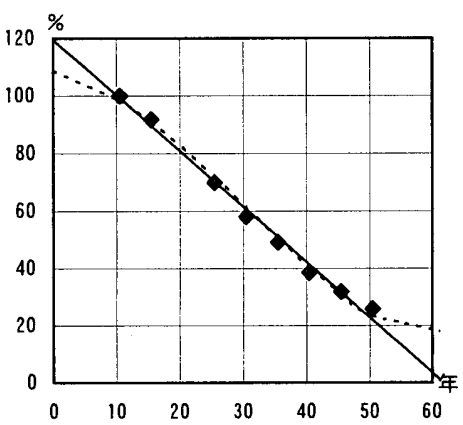

図 2. 同上（終戦～1950年）

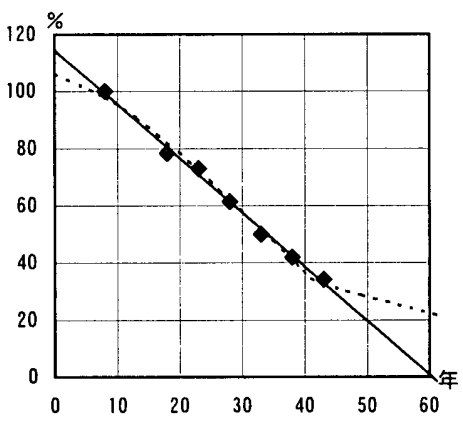

図3、同上（1951 60年）

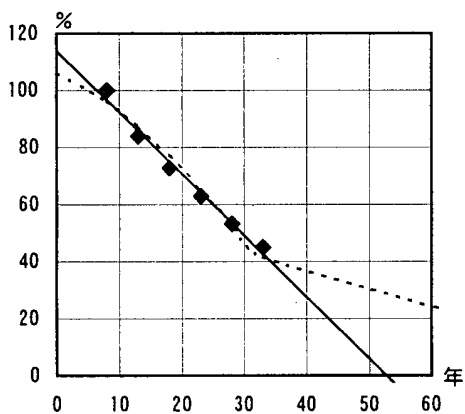

図 4. 同上（1961 70年）

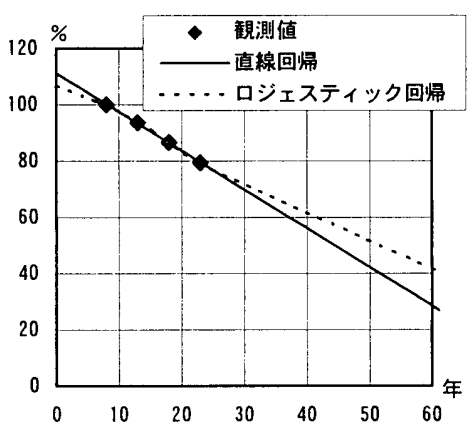

図 5. 同上（1971～80年） 
居住宅数と当該年の住宅着工戸数および前年、前々年のそれをプロ ットしたものが図 6 である。この図や居住宅数と当該年および前年、 前々年の着工戸数との相関などを比較検討すると、住宅統計の建築 時期は動態統計の着工時期に近いと考える方が両統計の示す傾向 はあう。このことは調查年の 9 月までのデータが (滅失後の) 次回 調查の結果に比べても極めて少ない(月数から判断すれば約 4 分の 3 を占める筈であるが半分程度の場合が多い、表 2 参照）こととも 辻褄があう。この他、大規模工事では、着工・工事・竣工と夕イム・ ラグを考慮すべきであるが、ここでは一律に住宅統計と動態統計に ついて同じ年をもって対応させることにした。

建築動態統計調査のデー夕は年間のフローであるからその積分 值は住宅統計調査の調査間隔 5 年分の増減に類似している筈であ る。横軸に住宅統計の調查年間を、縦軸に戸数をとって、住宅統計 調査における住宅総数および居住宅数の 5 年分の增減、住宅着工統 計の着工 (新設住宅) 户数から减失統計の居住用建築物の戸数を差 し引いた值の 5 年分の和（以下、結果 D という）を示すと、図 7 に あるように三者の間には相当の違いがある。

居住宅数については、その 8 年前まで前回調査結果と比較するこ とで、 5 年間に滅失した居住宅数が計算できる（直近 8 年を含まな いため害態より少なめの筈である。减失統計の值と区別するため、 以下、減分という）。减失户数と減分、そして着工戸数の 5 年分の!

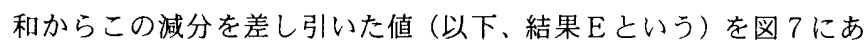
わせて示した。図から以下のようなことがいえる。

减失統計にある减失戸数と住宅統計から算出した減分との間に は大きな差がある

着工統計・减失統計から算出した結果Dより、住宅統計の隇分を

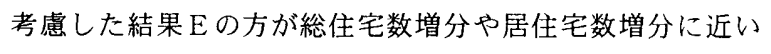

結果 $\mathrm{E}$ は近年こそ総住宅数増分に近いが、長期的な傾向は居住宅 数増分に類似している

これらのことから、減失戸数は小さすぎる可能性が高いこと、着 工戸数は原理的には総住宅数に対応するものであるが、結果からは 居住宅数により関係がありそうなこと、などが指摘できる。

\section{6. 住宅讋工戸数からの住宅ストックの隽定}

図 8 は図 1 図 5 の結果を参考に、あるN期区の残存率の変化を 模式的に描いたものである。前述したように竣工直後の滅失率（破 線の勾配 $\gamma$ ) は 4. で求めた回帰減失率（実線の勾配 $\beta$ ）より小さ い可能性が高く、着工戸数から1998年におけるストックを算定する に際しては、3.で求めた比例减失率（一点鎖線の勾配 $\alpha$ ) の方が 実態に近いと考えられる。そこで $\mathrm{G}$ 年の住宅着工戸数（表 2参照） がF戸である時、その1998年における住宅ストック戸数 $\mathrm{S}_{\mathrm{G} 98}$ を下 式に従って算定する。

$\mathrm{S}_{\mathrm{G} 98}=\mathrm{F}[1-\alpha \times(1998-\mathrm{G})]$

1970年以前の着工戸数は直近の居住宅数に比べて小さいとい う逆転現象にあるが（表 2 参照）、期区単位での相対的大小関係 は正しいとし、3. 同様、住宅統計の1998年の結果は経過年数を 考慮した各年の着工戸数に比例するとして减失率 $\delta$ (以下、見掛 け滅失率という、必然的に1970年以前の值は小さい)を逆算し、 その結果からストック戸数を算定することを考える。この計算の 過程で求められる見掛け减失率 $\delta$ は、着工戸数と居住宅数という全
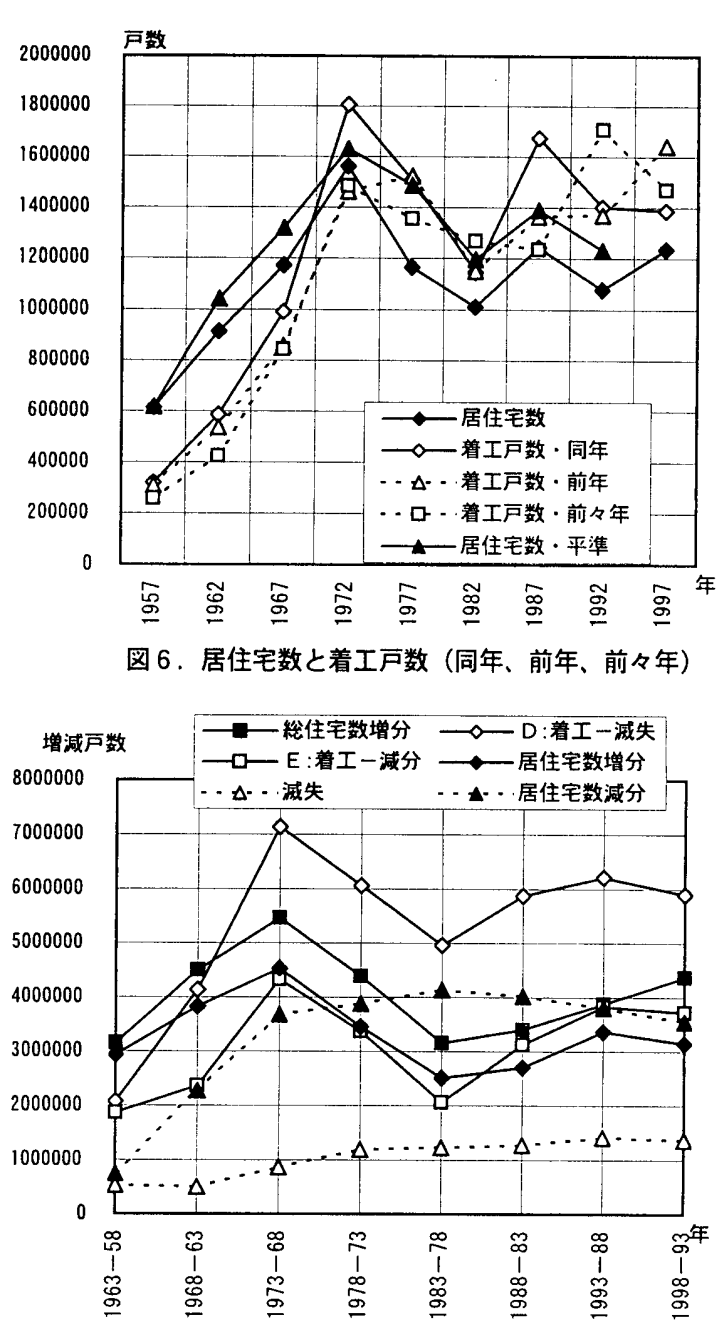

図 7. 住宅統計増隇と動態統計合計 (5 年間)

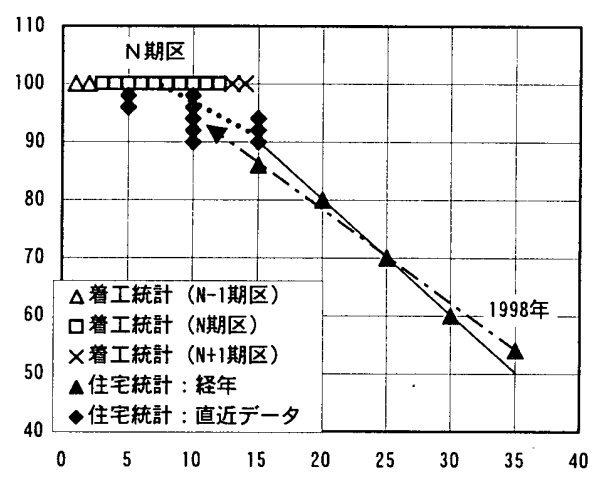

図 8. 残存率: $\alpha$ (此例)、 $\beta$ (回帰)、 $\gamma$ (直後)

く異なる資料に基づくものであり、これまで求めた减失率とは性格 を異にする。見掛け减失率が求められない1991〜 1993年について は、3．同様、便宜的に1981〜1990年のそれで代替する。これらの 結果を図 9 に示す。

図 9 に示した 4 種の年別住宅ストックのうち平準化していない 居住宅数による結果を除く 3 種を比較すると、平凖化した居住宅数 による結果 I と見掛け堿失率を使った着工戸数による結果 $\mathrm{K}$ とは 比較的類似した傾向を示し、比例减失率を使った着工統計による結 果 Jも1971年以降は、ほぼ同様の推移を示す。I とKの差異のIに 対する割合は平均 $9.06 \%$ 、梆準偏差 $5.73 \%$ であり、I とJの場合も 1971年以降に限れば、それぞれ $9.39 \%$ 、5.69\%である。結果 Jにお 
いて、1986年以降は結果 I を多少、上回りつつ推移 するが、居住世帯のない住宅を含むストック戸数 (総住宅数)に相当するほど大きな值ではない。

もともと住宅統計では建築時期、動態統計では着 工時期と、異なる時期を対象とした調査結果からの 算定であることを考えれば、結果 I、結果Kおよび 1971年以降の結果 J は、居住世帯のある住宅ストッ ク戸数の概算值として一応のレベルにあると思わ れる。また、結果 J、Kの手法によれば、1955年以 前や住宅統計の調査年以外の年、あるいは将来の年 を基点とする住宅ストックの概況を着工戸数から 算定することが可能となる。

\section{7. 跣再}

算定された結果についてその正確性を定量的に 検証するには固定資産台帳などによるのであろう が、その閲覧は一般には困難である。複数の公表資 料を照らし合わせ、矛盾がないかどうか、常識的な結果か否か、と いう視点で検討した。一連のプロセスを通して年別の住宅ストック に関して次のような知見が得られた。

1 ) 居住世帯のある住宅については每回の住宅統計調査に、その 前年から数年前まで年別のデータが1956年以降は概ねある。

2 ) 調査年の居住宅数は大きすぎると思われる場合が多いが、それ を含む10年単位のデータには一定の継続性が確保されている。

3 ) 住宅ストックの残存率の変化は、いずれの期区についても数年 〜十数年の範囲で、年に対してほぼ線形とみなすことができる。

4 ) 両調査から住宅ストックの増減を算定した結果によれば、建筑 動態統計の减失戸数は実態に比べ小さすぎると考えられる。

5 ) 調査年前後を平準化した住宅統計によるストックの推定値と、

期区毎の滅失率は等しいとして求めた着工戸数によるそれとは、

概ね類似した傾向を示す。

住宅統計調査の居住宅数、動態統計調査の着工戸数とも構造別、 建て方別、延べ床面積別など様々な住宅種別や都道府県別について 集計結果が公表されている。関連法規や各種基準類などとの関連を より厳密にみるためには、これら細目にわたる必要もある。本論文 で検討した方法をこれらの種別について適用した結果などについ ては稿を改めて述べる。

新辞 :

住宅統計調査に関するデータ収集とパソコン入力は東京工芸大 学卒業研究生 (当時) 森前麻美君、井田宗紀君などにお手伝いいた だいたものです。記して深く感謝する次第です。

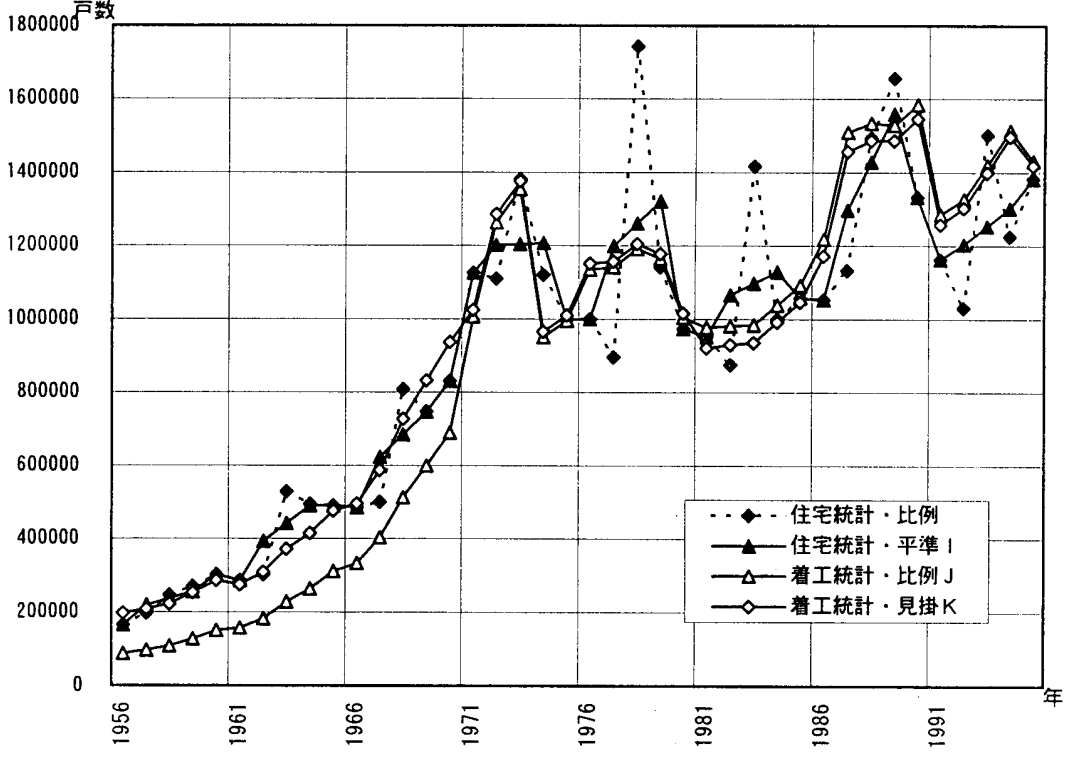

9. 1998年推定年別住宅ストック:居住宅数、同平準I、着エ戸数見掛K、同比例J

\section{孝文献 :}

1）住宅統計調查関倸：総務庁統計局（当初は総理府統計局）昭和23年住 宅調查から「昭和28年住宅統計調查結果報告」1954.3など、昭和 38年 から「昭和 38 年住宅統計調査報告 第 1 巻全国編」など、昭和 48作か ら「日本の住宅 炤和 48 年住宅統計調査の解説」などを加え、平成 10 年は「日本の住宅・土地 平成 10 年住宅・土地統計調查の解説」 2001 5による（最終原稿提出にあたり速報版から差し替え）

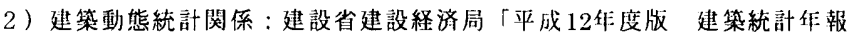
平成11年度計・11年計」2000.8など

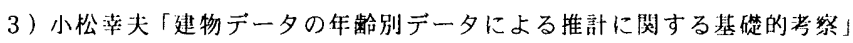
日本建築学会計西系論文報告集、第439号、pp91 99、1992.9

4) 加藤裕久、小松幸夫「木造尃用住宅の寿命に関する調榅研究」日本建 勧学会計画系論文報告集、第363号、pp20～26、1986.5

5 ）互犆伸吾、鉿木博志「减失住宅推計力法論および地域特性の検討（住 宅統計資料の分析一その 3 ）」日本建築学会論文報告集、第 267 号、 pp 141 153、1978.5

注 :

1）計算および作図にはパソコンソフトのExcel（マイクロソフト）、およ び、そのアドインソフト（桷社会情報サービス）を使用した。 